\title{
Kajian Efektivitas Teknik dan Bahan Konservasi pada Lontar di Bali
}

\author{
Ida Bagus Alit Sancana \\ Email: sancana@yahoo.com
}

\begin{abstract}
Abstrak: Naskah lontar adalah warisan budaya yang sangat rentan mengalami kerusakan. Oleh karena itu, diperlukan suatu tindakan konservasi yang benar untuk tetap menjaga keawetan naskah lontar tersebut dari pengaruh lingkungan sekitarnya. Berbagai cara konservasi dilakukan untuk melindungi naskah lontar dari kerusakan seperti menggunakan minyak cengkeh, minyak sereh, minyak kemiri, minyak wijen, campuran griserin, dan etanol, dan campuran aseton dan minyak sereh. Tulisan ini akan menguji keefektifan bahan-bahan konservasi tersebut dengan cara melakukan eksperimen pengujian.
\end{abstract}

Kata kunci: lontar, kerusakan, bahan konservasi, eksperimen, dan efektivitas

\begin{abstract}
:
Palm leaf manuscript is cultural heritage which can easily deteriorate. Various ways of conservation have been carried out in museums and people in Bali, such as by spreading the palm leaf manuscripts with clove oil, citronella oil, candle nut oil, sesame oil, mixture of glycerin and ethanol, and mixture of aceton and citronella oil. This research will do the test to conservation substance with experimental method.
\end{abstract}

Key word: palm leaf, deterioration, conservation substance, experiment, and effectiveness

Sebelum manusia mengenal kertas, banyak media yang digunakan untuk menulis, salah satunya seperti masyarakat Bali yang menggunakan daun dari pohon siwalan (borasus flabelliformis). Media tulis ini disebut dengan nama lontar.

Naskah lontar merupakan benda budaya yang memiliki nilai penting, seperti:

a. Nilai penting sejarah. Banyak manuskripmanuskrip lontar yang dibuat oleh tokoh-tokoh terkemuka di Bali.

b. Nilai penting pengetahuan. Isi yang terkandung dalam naskah lontar tersebut sarat dengan berbagai pengetahuan yang berguna bagi kehidupan, seperti arsitektur berupa tata cara pembuatan rumah di Bali (asta kosala kosali), hukum berupa peraturanperaturan adat (awig-awig) yang harus ditaati oleh masyarakat Bali, dan astrologi (ilmu perbintangan) yang banyak dipakai sebagai pedoman oleh petani di Bali untuk memulai pekerjaannya di sawah.

Jika dilihat dari daya tahannya, naskah lontar merupakan benda budaya yang tidak memiliki daya tahan kuat terhadap pengaruh lingkungan sekitar dibandingkan dengan benda budaya yang berasal dari jenis material anorganik. Maka dari itu, diperlukan suatu tindakan konservasi yang benar untuk tetap menjaga keawetan naskah lontar tersebut dari pengaruh lingkungan sekitar.

Berbagai cara konservasi dilakukan untuk menjaga keawetan naskah-naskah lontar yang disimpan oleh masyarakat atau di museum, salah satunya yaitu dengan cara melapisi naskah lontar menggunakan minyak kemiri (candle nut oil), minyak wijen (sesame oil), minyak cengkeh (clove oi), minyak sereh (citronella oi), campuran antara gliserin dan etanol, dan campuran antara aseton dengan minyak sereh (citronella oil).

Penelitian ini akan menguji bahan-bahan konservasi di atas, tujuannya adalah untuk mendapatkan teknik dan bahan konservasi yang efektif untuk melindungi lontar dari kerusakan. Untuk itu perlu dijelaskan bagaimana kondisi lontar yang telah mengalami proses pengujian teknik dan bahan konservasi apakah yang efektif digunakan untuk melindungi lontar di Bali.

\section{Metode Penelitian}

Metode yang digunakan dalam penelitian ini adalah teknik eksperimental. Penelitian eksperimental adalah metode penelitian yang dilakukan untuk 
mengetahui akibat yang ditimbulkan dari suatu perlakuan yang diberikan secara sengaja oleh peneliti terhadap objek yang akan diteliti (Hadi, 1985: 12). Adapun tahapan eksperimen, sebagai berikut:

a. Penentuan objek eksperimen

Jumlah lontar yang akan dieksperimen yaitu 352 lembar, dengan ukuran panjang $5 \mathrm{~cm}$ dan lebar 3,5 $\mathrm{cm}$.

\section{b. Penentuan bahan konservasi}

Bahan yang digunakan untuk mengonservasi lontar berjumlah 44 jenis bahan. Takaran yang digunakan untuk mencampur dua atau lebih bahan konservasi yaitu 1:1 (sama banyaknya).

\section{c. Cara eksperimen}

Sebelum dilakukan pengujian, lontar dilapisi bahan konservasi. Pelapisan dilakukan dengan menggunakan kapas yang telah dibasahi bahan konservasi, kemudian dioleskan ke permukaan (pada sisi depan dan belakang) lontar. Setelah itu, lontar didiamkan selama 1 hari agar bahan konservasi meresap ke permukaan lontar. Tahap pengujian yang akan dilakukan di antaranya:

1. Menguji ketahanan lontar terhadap kondisi suhu tinggi

Pengujian ini dilakukan dengan cara menyimpan lontar di kaleng yang tertutup, kemudian kaleng tersebut disinari dengan lampu pijar yang memiliki daya 150 watt dengan suhu yang dihasilkan sebesar $31^{\circ} \mathrm{C}$ (berdasarkan pengukuran dengan menggunakan thermometer). Pemilihan lampu pijar ini karena suhu yang dihasilkan di atas suhu ideal untuk penyimpanan koleksi bahan pustaka. Menurut Jyotshna Sahoo (2004: 15) idealnya suhu tempat penyimpanan koleksi naskah berkisar antara $20^{\circ} \mathrm{C}-25^{\circ} \mathrm{C}$, sedangkan menurut IFLA (International Federation of Library Associations and Institution) idealnya berkisar antara $16^{\circ} \mathrm{C}-21^{\circ} \mathrm{C}$ (Dureau and Clements, 1986: 20). Pengujian ini dilakukan selama 18 hari.

2. Menguji ketahanan lontar terhadap kondisi udara yang lembab

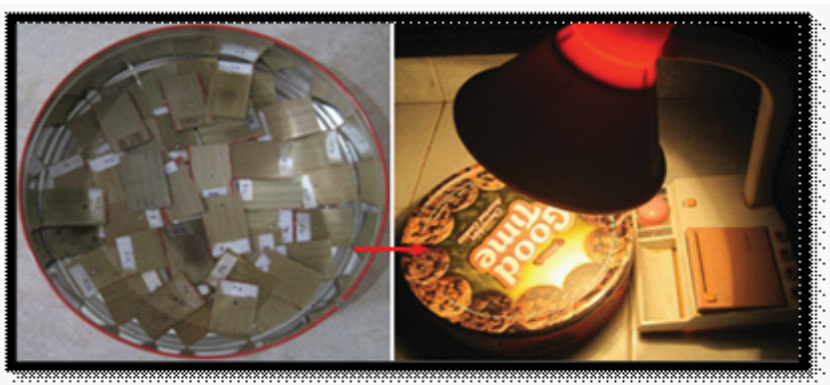

Gambar 1. Pengujian lontar terhadap kondisi suhu tinggi dengan menyimpan lontar di kaleng yang dipanasi lampu pijar

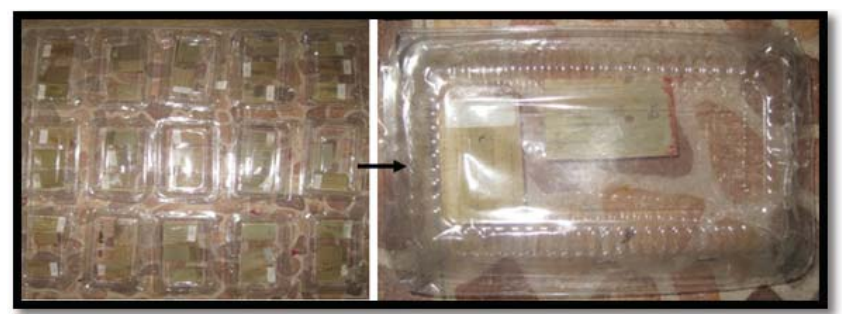

Gambar 2. Pengujian ketahanan Iontar terhadap kondisi udara lembab dengan menyimpan lontar di kotak plastik

Pengujian ini dilakukan dengan cara menyimpan lontar di kotak plastik yang kedap udara, kemudian diletakan di ruangan tertutup tanpa ventilasi dan jauh dari sumber cahaya. Tujuannya adalah untuk mempercepat proses kerusakan pada lontar. Berdasarkan pengukuran dengan menggunakan hygrometer, RH (Relative Humidity) di ruang penyimpanan lontar mencapai 75\%. Kelembaban tersebut sangat mendukung dalam mempercepat proses pertumbuhan jamur pada lontar, karena jamur dapat tumbuh pesat dalam suasana yang lembab sekitar 70\% ke atas (Agrawal, 1977: 42). Pengujian ini dilakukan selama 34 hari.

3. Menguji ketahanan lontar terhadap pengaruh fluktuasi suhu

Pengujian ini dilakukan dengan cara menyimpan lontar di ruangan ber-AC. AC tersebut diaktifkan selama 8 jam (dari pukul 08.00 - 16.00) dan dinonaktifkan selama 16 jam (dari pukul 16.00 08.00). Suhu minimum ruangan yaitu $20^{\circ} \mathrm{C}$, suhu maksimum ruangan $29^{\circ} \mathrm{C}$, dan fluktuasi suhu yang terjadi di ruangan yaitu $9{ }^{\circ} \mathrm{C}$. Pengamatan suhu ruangan dilakukan dengan menggunakan thermometer. Pengujian ini dilakukan selama 42 hari.

4. Menguji ketahanan lontar terhadap pengaruh radiasi cahaya 


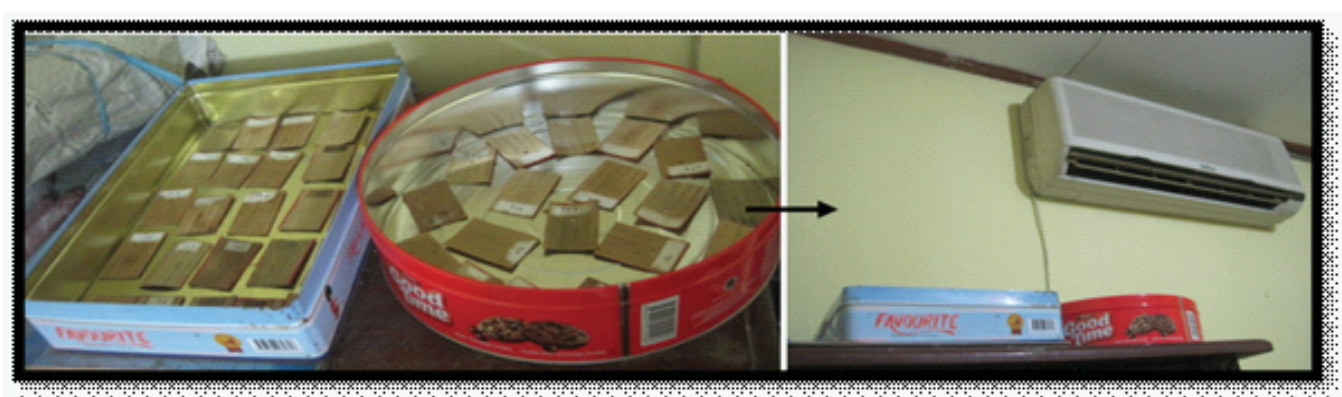

Gambar 3. Pengujian ketahanan lontar terhadap fluktuasi suhu dengan meletakkan lontar di ruangan ber-AC yang diaktifkan selama 8 jam

Pengujian ini dilakukan dengan cara menyinari lontar menggunakan lampu pijar. Lampu pijar yang digunakan untuk menyinari lontar memiliki daya sebesar 150 watt dengan intensitas cahaya yang dihasilkan sebesar 180 lux (berdasarkan pengukuran dengan menggunakan lux meter) dan suhu yang dihasilkan sebesar $31^{\circ} \mathrm{C}$ (berdasarkan pengukuran dengan menggunakan thermometer). Proses penyinaran lontar ini dilakukan secara terus menerus (24 jam). Pemilihan lampu pijar ini karena intensitas cahaya yang dihasilkan oleh lampu ini di atas standar intensitas cahaya untuk koleksi berbahan organik yaitu 50 lux (Jessica, 2006: 35). Pengujian ini dilakukan selama 18 hari.

5. Menguji ketahanan lontar terhadap serangan serangga perusak

Pengujian ini dilakukan dengan cara meletakkan lontar di kaleng, kemudian dimasukkan rayap ke kaleng yang telah berisi lontar tersebut. Pengujian lontar ini dilakukan selama 20 hari.

6. Menguji ketahanan lontar dalam kondisi nyata Pengujian ini dilakukan dengan cara (1) menyimpan lontar di kotak kayu, kemudian kotak kayu tersebut disimpan di ruangan yang memiliki ventilasi udara dan (2) menyimpan lontar di kotak kayu dan lemari kaca, kemudian kotak kayu dan lemari kaca tersebut disimpan di ruangan ber-AC. AC ini akan diaktifkan selama 8 jam (dari pukul 08.00-16.00) dan dinonaktifkan selama 16 jam (dari pukul 16.0008.00). Penggunaan AC ini dilakukan selama 5 hari dalam seminggu, sesuai dengan kebiasaan di museum-museum yang menjadi lokasi dalam penelitian ini. Suhu minimum ruangan pada pecobaan pertama yaitu $27^{\circ} \mathrm{C}$, suhu maximum ruangan $29^{\circ} \mathrm{C}$, dan Fluktuasi suhu yang terjadi

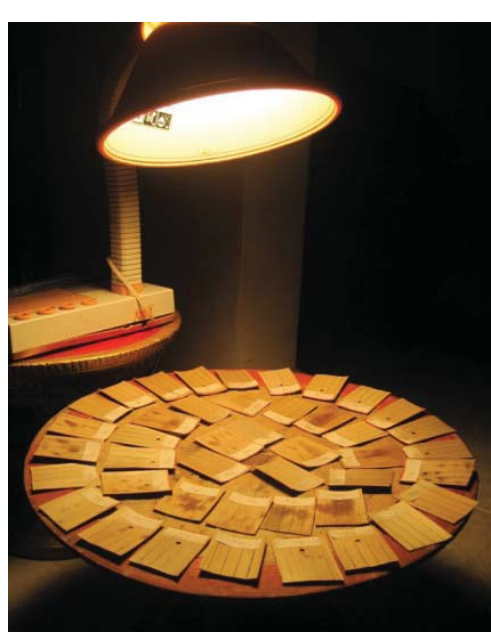

Gambar 4. Pengujian ketahanan lontar terhadap pengaruh radiasi cahaya dengan menyinari lontar menggunakan lampu pijar

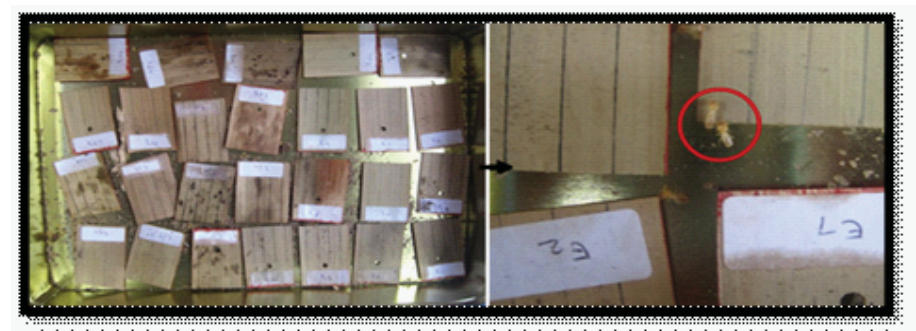

Gambar 5. Pengujian ketahanan lontar terhadap serangan serangga dengan menyimpan di kaleng yang berisi rayap

diruangan yaitu $2^{\circ} \mathrm{C}$. Suhu minimum ruangan pada percobaan kedua dan ketiga yaitu $20^{\circ} \mathrm{C}$, suhu maximum ruangan $29^{\circ} \mathrm{C}$, dan fluktuasi suhu yang terjadi diruangan yaitu $9^{\circ} \mathrm{C}$. Pengujian ini dilakukan selama 42 hari.

d. Penentuan kode eksperimen

Kode-kode eksperimen yang diberikan pada lontar, terdiri dari dua kode yaitu kode huruf dan kode angka (lihat lampiran 1). Kode huruf merupakan kode pengujian yang akan dilakukan terhadap lontar, contohnya A adalah kode untuk lontar yang diuji ketahanannya terhadap kondisi 


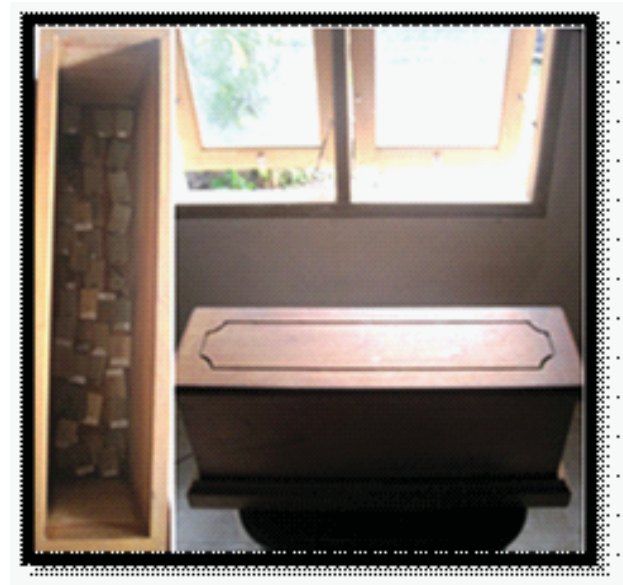

Gambar 6. Penyimpanan lontar di keropak (kotak kayu) dan diletakan di ruangan berventilasi

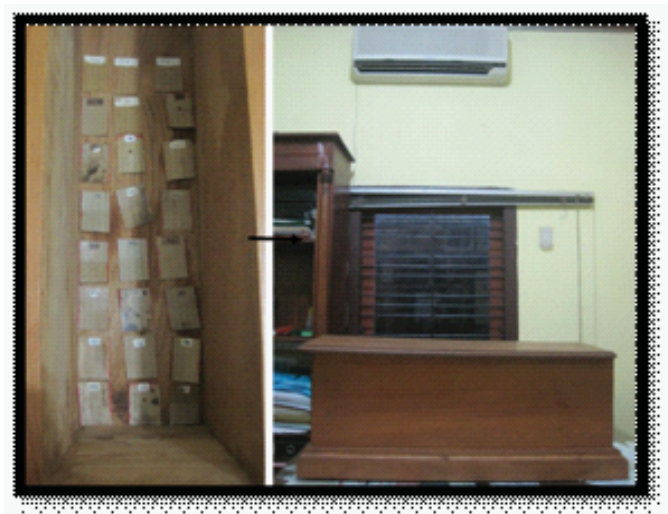

Gambar 7. Penyimpanan lontar di keropak (kotak kayu) dan diletakan di ruangan ber-AC yang diaktifkan selama 8 jam

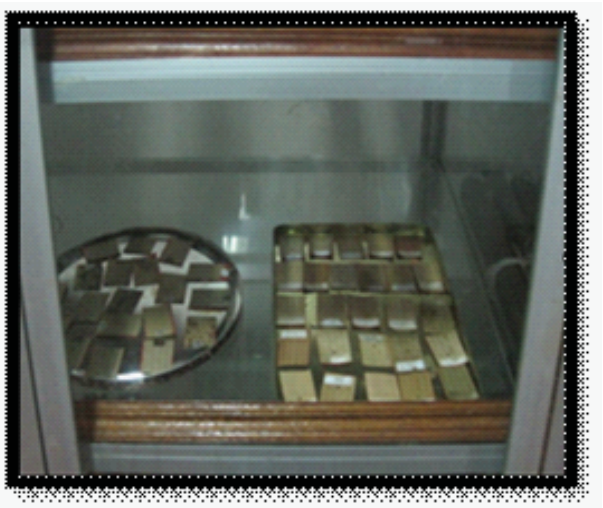

Gambar 8. Penyimpanan lontar di lemari kaca

suhu tinggi. Kode angka merupakan kode bahan konservasi yang akan dioleskan pada lontar, contohnya 1 adalah kode bahan konservasi untuk minyak kemiri. Jadi kode A1 adalah kode lontar yang dikonservasi dengan minyak kemiri dan diuji pada suhu tinggi.

\section{e. Tolok ukur pengamatan}

Tolok ukur atau parameter yang digunakan untuk mengamati kualitas lontar yang telah diuji yaitu:

\section{Kelenturan lontar}

Kelenturan lontar dapat diamati dengan cara membengkokkan lontar $180^{\circ}$. Kualitas kelenturan lontar baik apabila lontar dibengkokan $180^{\circ}$ tidak patah. Kualitas kelenturan lontar kurang apabila lontar dibengkokan $180^{\circ}$ mudah patah.

2. Warna lontar

Warna lontar dapat diamati dengan cara melihat warna lontar setelah mengalami proses pengujian. Pengamatan warna lontar ini dilakukan dengan bantuan color soil charts. Warna awal lontar sebelum diuji berdasarkan color soil charts adalah coklat sedang (5YR 3/4).

\section{Ukuran lontar}

Ukuran lontar dapat diamati dengan cara mengukur panjang dan lebar lontar setelah proses pengujian. Pengukuran dilakukan dengan menggunakan penggaris. Ukuran awal lontar yang diuji yaitu panjang $5 \mathrm{~cm}$ dan lebar $3,5 \mathrm{~cm}$.

4. Jamur pada lontar

Untuk mengetahui lontar ditumbuhi jamur, dapat diamati dengan cara melihat pertumbuhan spora pada permukaan lontar. Pengamatan spora yang menempel pada lontar dapat dilihat secara kasat mata. Spora yang tumbuh pada lontar awalnya berupa bintik-bintik berwarna putih dan jika disentuh terasa seperti kapas.

\section{Bentuk lontar}

Bentuk lontar dapat diamati dengan cara membandingkan bentuk awal lontar sebelum diuji dan setelah mengalami proses pengujian. Bentuk awal lontar yaitu persegi panjang dengan permukaan yang rata.

\section{Hasil Eksperimen}

A. Hasil pengujian ketahanan lontar

Sebelum dilakukan pengujian sudah terjadi perubahan warna pada lontar. Perubahan warna tersebut terjadi setelah lontar didiamkan selama 1 hari. Hasil pengamatan terhadap warna lontar dapat dilihat pada Tabel 1. 
Perubahan warna lontar menjadi coklat kehitaman (5YR 2/2) karena pengaruh warna hitam yang berasal dari minyak kemiri. Perubahan warna lontar menjadi coklat sedang (5YR 3/4) ditambah dengan warna merah sangat kehitaman (10R 2/2) berbentuk bulatan-bulatan menyerupai noda karena minyak kemiri tidak dapat larut (tercampur) dengan gliserin sehingga menimbulkan bulatanbulatan berwarna merah sangat gelap tersebut. Ini menunjukan bahwa bahan-bahan konservasi tersebut kurang efektif untuk mempertahankan warna awal lontar.

Pengujian lontar pada suhu tinggi menunjukkan hasil; terjadi penurunan kualitas kelenturan lontar. Data penurunan kualitas kelenturan lontar selama dipanaskan pada suhu $31^{\circ} \mathrm{C}$, dapat dilihat pada Tabel 2. Berdasarkan Tabel 2 di atas, bahan-bahan konservasi mampu melindungi lontar dari pengaruh suhu yang tinggi. Hal ini dapat dilihat dari perbandingan lontar yang tidak diolesi bahan konservasi (A0) lebih mudah mengalami penurunan kualitas kelenturan dibandingkan dengan lontar yang telah diolesi bahan konservasi. Jika dilihat dari ke-44 jenis bahan konservasi tersebut, 21 jenis bahan konservasi lebih ampuh melindungi lontar dari pengaruh suhu tinggi $\left(31^{\circ} \mathrm{C}\right)$. Hal ini karena bahan-bahan konservasi tersebut tidak cepat menguap ketika dipanaskan, sehingga membuat lontar tidak mudah kering. Kelenturan lontar mulai berkurang setelah dipanaskan selama 18 hari.

Hasil pengujian lontar pada kondisi lembab (75\%) yaitu lontar ditumbuhi spora. Data untuk pengamatan pertumbuhan spora pada lontar dapat dilihat pada tabel 3 .

Berdasarkan Tabel 3, diketahui bahwa tidak selamanya bahan-bahan konservasi yang digunakan efektif untuk menghambat pertumbuhan jamur pada lontar. Hal ini dilihat dari perbandingan antara lontar yang diberikan bahan konservasi lebih cepat ditumbuhi spora dibandingkan dengan lontar yang tidak diberikan

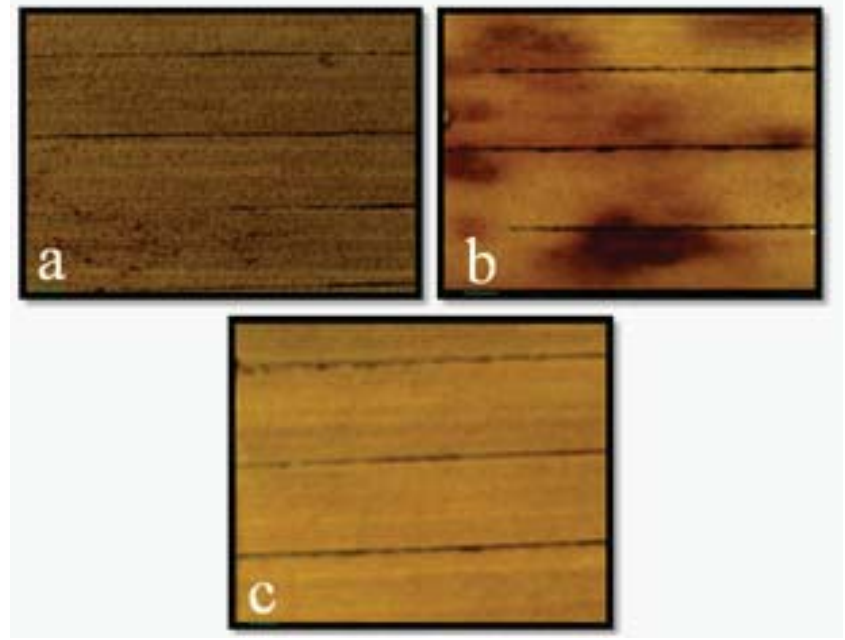

Gambar 7. (a) Lontar berwarna coklat kehitaman (5YR 2/2), (b) lontar berwarna dasar coklat sedang (5YR 3/4) ditambah dengan warna merah sangat kehitaman (10R 2/2) berbentuk bulatan-bulatan menyerupai noda, dan (c) lontar berwarna coklat sedang (skala 5YR3/4)

Tabel 1. Pengamatan Warna Lontar

\begin{tabular}{|c|c|}
\hline Kondisi Perubahan Warna Lontar & No. Bahan Konservasi \\
\hline Warna tidak berubah (coklat sedang (5YR 3/4)) & $\begin{array}{l}2,3,4,5,6,22,23,24,25,26,27 \\
28,29,30,31,32,33,34,36,37 \\
39, \text { dan } 41\end{array}$ \\
\hline $\begin{array}{l}\text { Berubah menjadi coklat kehitaman } \\
(5 Y R 2 / 2)\end{array}$ & $\begin{array}{l}1,7,8,9,11,14,17,20,35,38 \\
40, \text { dan } 44\end{array}$ \\
\hline $\begin{array}{l}\text { Berubah menjadi coklat sedang (5YR } 3 / 4) \text { ditambah dengan warna } \\
\text { merah sangat kehitaman }(10 \mathrm{R} 2 / 2) \text { berbentuk bulatan-bulatan } \\
\text { menyerupai noda }\end{array}$ & $\begin{array}{l}10,12,13,15,16,18,19,21,42 \\
\text { dan } 43\end{array}$ \\
\hline
\end{tabular}

Tabel 2. Data Penurunan Kualitas Kelenturan Lontar Selama Dipanaskan pada Suhu $31^{\circ} \mathrm{C}$

\begin{tabular}{cl}
$\begin{array}{c}\text { Lama } \\
\text { Paparan }\end{array}$ & \multicolumn{1}{c}{$\begin{array}{c}\text { Lontar yang Mengalami } \\
\text { Penurunan Kualitas Kelenturan }\end{array}$} \\
\hline 8 hari & $\mathrm{A}^{*}$ \\
\hline 10 hari & $\mathrm{A} 1, \mathrm{~A} 6, \mathrm{~A} 11$ \\
\hline 12 hari & $\mathrm{A} 3, \mathrm{~A} 4, \mathrm{~A} 7, \mathrm{~A} 8, \mathrm{~A} 17, \mathrm{~A} 24, \mathrm{~A} 30, \mathrm{~A} 33, \mathrm{~A} 35$, dan $\mathrm{A} 38$ \\
\hline 13 hari & $\mathrm{A} 2, \mathrm{~A} 9, \mathrm{~A} 14, \mathrm{~A} 20, \mathrm{~A} 22, \mathrm{~A} 27, \mathrm{~A} 34, \mathrm{~A} 37, \mathrm{~A} 40$, dan $\mathrm{A} 44$ \\
\hline 18 hari & $\mathrm{A} 5, \mathrm{~A} 10, \mathrm{~A} 12, \mathrm{~A} 13, \mathrm{~A} 15, \mathrm{~A} 16, \mathrm{~A} 18, \mathrm{~A} 19, \mathrm{~A} 21, \mathrm{~A} 23, \mathrm{~A} 25, \mathrm{~A} 26, \mathrm{~A} 28, \mathrm{~A} 29, \mathrm{~A} 31, \mathrm{~A} 32, \mathrm{~A} 36, \mathrm{~A} 39$, \\
& $\mathrm{A} 41, \mathrm{~A} 42$, dan $\mathrm{A} 43$
\end{tabular}

* Keterangan: lontar yang tidak diolesi bahan konservasi 
bahan konservasi (B0).

Jenis-jenis jamur yang tumbuh pada lontar terdiri dari fusarium, penicillium, dan aspergillus. Untuk mengetahui jenis jamur yang tumbuh pada

Tabel 3 Data Pertumbuhan Spora pada Lontar

\begin{tabular}{|c|c|c|}
\hline $\begin{array}{l}\text { Lama } \\
\text { penyimpanan }\end{array}$ & Lontar yang diuji & $\begin{array}{l}\text { Jenis jamur yang tumbuh } \\
\text { pada lontar }\end{array}$ \\
\hline \multirow{11}{*}{7 hari } & B10 & Fusarium, penicillium, dan aspergillus \\
\hline & B12 & Penicillium, dan aspergillus \\
\hline & B16 & Fusarium, penicillium, dan aspergillus \\
\hline & B18 & Penicillium dan aspergillus \\
\hline & B19 & Penicillium, dan aspergillus \\
\hline & B21 & Fusarium, penicillium, dan aspergillus \\
\hline & B28 & Fusarium, penicillium, dan aspergillus \\
\hline & B29 & Fusarium, penicillium, dan aspergillus \\
\hline & B31 & Fusarium dan penicillium \\
\hline & B32 & Fusarium dan penicillium \\
\hline & B36 & Fusarium dan aspergillus \\
\hline \multirow{5}{*}{10 hari } & B39 & Fusarium, penicillium, dan aspergillus \\
\hline & B1 & Fusarium, penicillium, dan aspergillus \\
\hline & B8 & Penicillium dan aspergillus \\
\hline & B35 & Fusarium, penicillium, dan aspergillus \\
\hline & B41 & Fusarium dan aspergillus \\
\hline \multirow{3}{*}{10 hari } & B42 & Penicillium dan aspergillus \\
\hline & B43 & Fusarium, penicillium, dan aspergillus \\
\hline & B44 & Fusarium, penicillium, dan aspergillus \\
\hline \multirow{3}{*}{12 hari } & $\mathrm{B} 0^{*}$ & Penicillium, dan aspergillus \\
\hline & B37 & Penicillium, dan aspergillus \\
\hline & B38 & Fusarium dan aspergillus \\
\hline 15 hari & B11 & Fusarium, penicillium, dan aspergillus \\
\hline \multirow{3}{*}{17 hari } & B13 & Fusarium, penicillium, dan aspergillus \\
\hline & B15 & Fusarium dan aspergillus \\
\hline & B33 & Fusarium, penicillium, dan aspergillus \\
\hline \multirow{3}{*}{19 hari } & B3 & Fusarium dan penicillium \\
\hline & B34 & Fusarium dan penicillium \\
\hline & B40 & Fusarium, penicillium, dan aspergillus \\
\hline \multirow{3}{*}{25 hari } & B9 & Fusarium, penicillium, dan aspergillus \\
\hline & B25 & Fusarium dan aspergillus \\
\hline & B27 & Penicillium, dan aspergillus \\
\hline \multirow{3}{*}{27 hari } & B6 & Fusarium, penicillium, dan aspergillus \\
\hline & B17 & Fusarium, penicillium, dan aspergillus \\
\hline & B30 & Fusarium, penicillium, dan aspergillus \\
\hline \multirow[t]{2}{*}{30 hari } & $\mathrm{B} 20$ & Penicillium, dan aspergillus \\
\hline & B26 & Penicillium, dan aspergillus \\
\hline \multirow{3}{*}{32 hari } & B7 & Fusarium dan aspergillus \\
\hline & B14 & Fusarium dan penicillium \\
\hline & B22 & Fusarium, penicillium, dan aspergillus \\
\hline \multirow{5}{*}{34 hari } & B2 & penicillium, dan aspergillus \\
\hline & B4 & Fusarium dan penicillium \\
\hline & B5 & Aspergillus dan Fusarium \\
\hline & B23 & Fusarium, penicillium, dan aspergillus \\
\hline & B24 & Penicillium, dan aspergillus \\
\hline
\end{tabular}

* Keterangan: lontar yang tidak diolesi bahan konservasi 


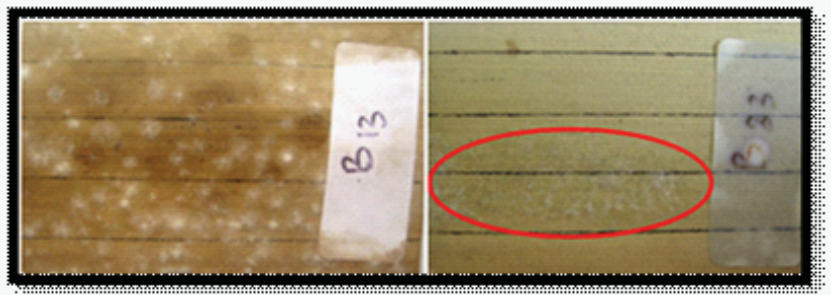

Gambar 8. Spora yang tumbuh pada Lontar

lontar-lontar tersebut, dilakukan metode inkubasi pada setiap lontar yang ditumbuhi spora. Sporaspora yang tumbuh pada lontar merupakan hasil kontaminasi dari berbagai jenis jamur. Tahapan inkubasi lontar yaitu (Samson et al., 1995: 45):

a. Lontar dipotong kecil dengan ukuran $1 \mathrm{~cm} \times 1$ $\mathrm{cm}$

b. Lontar dicelupkan ke beaker glass yang berisi alkohol 70\% selama 2 menit untuk menghilangkan kontaminasi pada bagian luarnya

c. Lontar tersebut kemudian dibilas dengan cara mencelupkan ke akuades steril sebanyak 3 kali dan diletakkan pada permukaan media PDA (Potato Dextrose Agar) yang telah diisi dengan cloramfenikol (100 mg/L) d. Tahapan akhir, lontar diinkubasi di kotak inkubator pada suhu $27-28^{\circ} \mathrm{C}$ selama 5 hari.

Miselium yang tumbuh pada lontar selanjutnya direisolasi pada media PDA (Potato Dextrose Agar) sampai ditemukan jamur pada lontar. Masingmasing jamur kemudian diamati secara morfologi (berdasarkan warna koloni dan teksturnya) dengan menggunakan mikroskop.

Hasil pengujian lontar pada pengaruh fluktuasi suhu yaitu terjadi perubahan bentuk pada lontar. Data perubahan bentuk lontar selama disimpan di ruangan ber-AC dapat dilihat pada Tabel 4 .

Berdasarkan Tabel 4 di atas, perubahan bentuk yang terjadi pada lontar yaitu berbentuk gelombang, berbentuk cekung, melengkung pada bagian ujung dan berbentuk cembung.

Hasil pengujian lontar pada pengaruh radiasi cahaya yaitu terjadi perubahan warna pada lontar dan kualitas kelenturan lontar berkurang. Data hasil pengamatan terhadap warna lontar ketika disinari lampu pijar dengan intensitas cahaya 180 lux, dapat dilihat pada Tabel 5.

Tabel 4. Data Perubahan Bentuk Lontar Selama Penyimpanan di Ruangan Ber-AC yang Diaktifkan Selama 8 jam

\begin{tabular}{|c|c|c|}
\hline $\begin{array}{c}\text { Lama } \\
\text { Penyimpanan }\end{array}$ & $\begin{array}{c}\text { Lontar yang } \\
\text { diuji }\end{array}$ & Perubahan bentuk lontar \\
\hline \multirow{12}{*}{37 hari } & $\mathrm{C} 10$ & Melengkung pada bagian ujung \\
\hline & $\mathrm{C} 12$ & Melengkung pada bagian ujung \\
\hline & $\mathrm{C} 13$ & Melengkung pada bagian ujung \\
\hline & C15 & Melengkung pada bagian ujung \\
\hline & C16 & Berbentuk cembung \\
\hline & C18 & Menyerupai bentuk gelombang \\
\hline & C19 & Berbentuk cekung \\
\hline & $\mathrm{C} 20$ & Melengkung pada bagian ujung \\
\hline & $\mathrm{C} 21$ & Menyerupai bentuk gelombang \\
\hline & $\mathrm{C} 25$ & berbentuk cembung \\
\hline & $\mathrm{C} 26$ & Melengkung pada bagian ujung \\
\hline & $\mathrm{C} 27$ & Berbentuk cekung \\
\hline \multirow{10}{*}{37 hari } & $\mathrm{C} 28$ & Berbentuk cembung \\
\hline & $\mathrm{C} 29$ & Melengkung pada bagian ujung \\
\hline & C31 & Berbentuk cekung \\
\hline & C32 & Berbentuk cekung \\
\hline & C36 & Menyerupai bentuk gelombang \\
\hline & C37 & Berbentuk cekung \\
\hline & C38 & Melengkung pada bagian ujung \\
\hline & C39 & berbentuk cembung \\
\hline & $\mathrm{C} 40$ & Berbentuk cekung \\
\hline & C41 & Berbentuk cembung \\
\hline
\end{tabular}




\begin{tabular}{|c|c|c|}
\hline \multirow{3}{*}{37 hari } & C42 & Berbentuk cekung \\
\hline & C43 & Menyerupai bentuk gelombang \\
\hline & C44 & Berbentuk cekung \\
\hline \multirow{6}{*}{38 hari } & $\mathrm{CO}^{*}$ & Berbentuk cembung \\
\hline & C5 & Berbentuk cembung \\
\hline & $\mathrm{C9}$ & Melengkung pada bagian ujung \\
\hline & C11 & Berbentuk cembung \\
\hline & C14 & Berbentuk cekung \\
\hline & C17 & Melengkung pada bagian ujung \\
\hline \multirow{14}{*}{42 hari } & $\mathrm{C} 22$ & Melengkung pada bagian ujung \\
\hline & $\mathrm{C} 23$ & Berbentuk cembung \\
\hline & $\mathrm{C} 24$ & Berbentuk cembung \\
\hline & C30 & Berbentuk cekung \\
\hline & C1 & Berbentuk cembung \\
\hline & $\mathrm{C} 2$ & Melengkung pada bagian ujung \\
\hline & C3 & Melengkung pada bagian ujung \\
\hline & $\mathrm{C} 4$ & Melengkung pada bagian ujung \\
\hline & C6 & Berbentuk cembung \\
\hline & $\mathrm{C7}$ & Berbentuk cekung \\
\hline & $\mathrm{C} 8$ & Berbentuk cembung \\
\hline & C33 & Melengkung pada bagian ujung \\
\hline & C34 & Berbentuk cekung \\
\hline & $\mathrm{C} 35$ & Melengkung pada bagian ujung \\
\hline
\end{tabular}

* Keterangan: lontar yang tidak diolesi bahan konservasi

Berdasarkan Tabel 5, lontar yang berwarna coklat kehitaman (5YR 2/2) akan berubah warnanya menjadi coklat pucat (5YR 5/2). Lontar yang berwarna coklat sedang (5YR 3/4) ditambah dengan warna merah sangat kehitaman (10R 2/2) berbentuk bulatan-bulatan menyerupai noda akan berubah
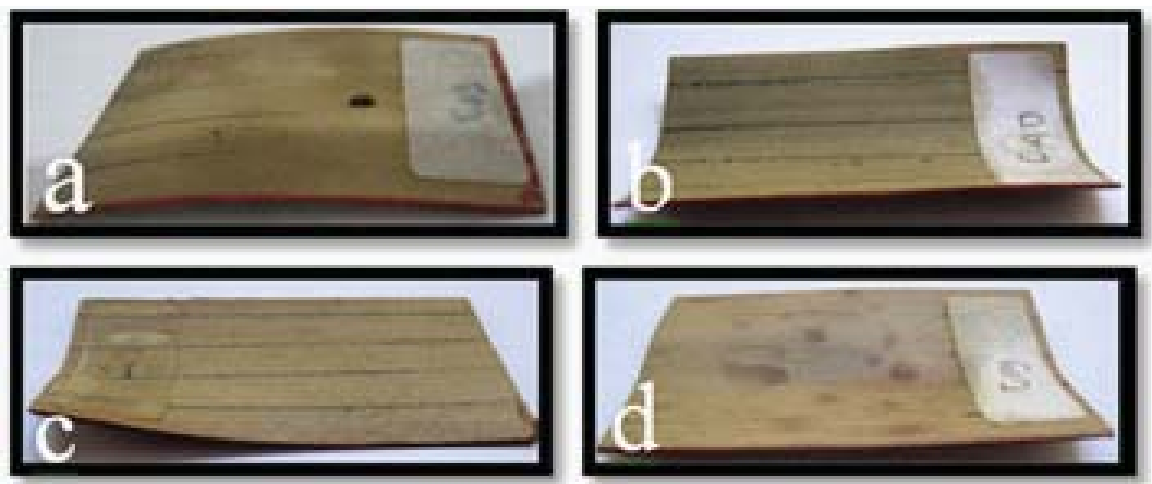

Gambar 9. (a) Lontar yang berbentuk cembung,

(b) lontar yang berbentuk cekung,

(c) lontar yang melengkung pada bagian ujung, dan

(d) lontar yang bentuk gelombang

Tabel 5. Data Pengamatan Warna Lontar Selama Disinari Lampu Pijar dengan Intensitas Cahaya 180 Lux

\begin{tabular}{lll}
$\begin{array}{c}\text { Lama } \\
\text { penyinaran }\end{array}$ & \multicolumn{1}{c}{ Perubahan warna pada lontar } & \multicolumn{1}{c}{ Lontar yang diuji } \\
& $\begin{array}{l}\text { Berubah menjadi coklat kehitaman (5YR } \\
\text { 2/2) }\end{array}$ & $\begin{array}{l}\text { C1, C7, C8, C9, C11, C14, C17, C20, } \\
\text { C35, C38, C40, dan C44 }\end{array}$ \\
\hline 0 hari\# & $\begin{array}{l}\text { Berubah menjadi coklat sedang (5YR 3/4) } \\
\text { ditambah dengan warna merah sangat } \\
\text { kehitaman (10R 2/2) berbentuk bulatan- } \\
\text { bulatan menyerupai noda }\end{array}$ & $\begin{array}{l}\text { C10, C12, C13, C15, C16, C18, C19, } \\
\text { C21, C42, dan C43 }\end{array}$ \\
\hline
\end{tabular}




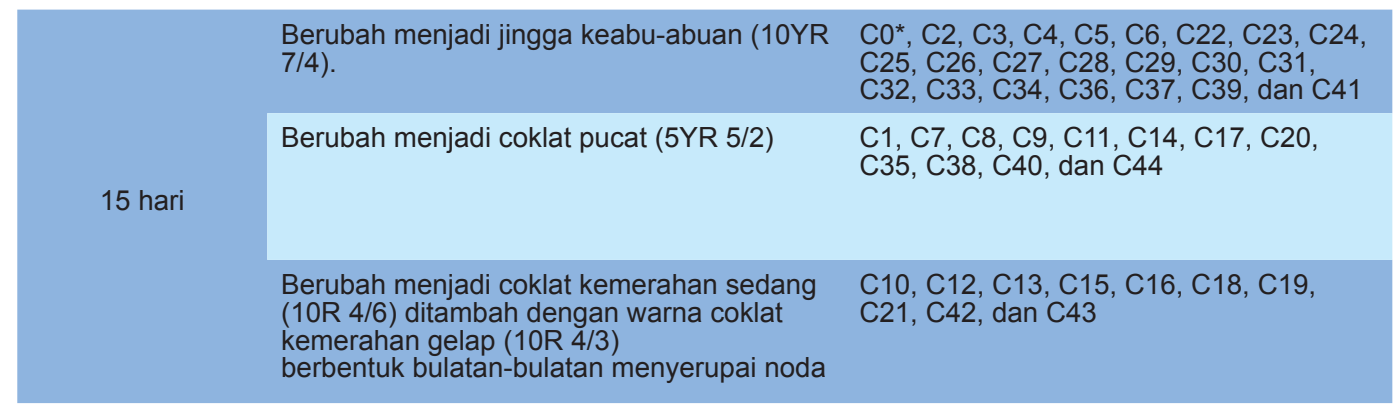

* Keterangan: lontar yang tidak diolesi bahan konservasi \# Keterangan: hari sebelum dilakukan pengujian lontar

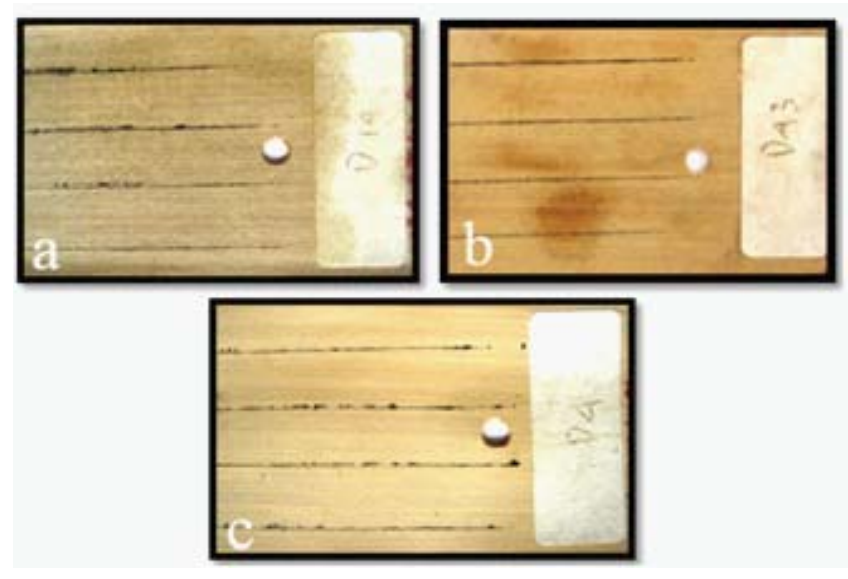

Gambar 10. (a) Lontar berwarna coklat pucat (5YR 5/2), (b) lontar berwarna dasar coklat kemerahan sedang (10R 4/6) ditambah dengan warna coklat kemerahan gelap (10R 4/3) berbentuk bulatanbulatan yang menyerupai noda, dan (c) lontar yang berwarna jingga keabu-abuan (10YR 7/4)

warnanya menjadi coklat kemerahan sedang (10R 4/6) ditambah dengan warna coklat kemerahan gelap (10R 4/3) berbentuk bulatan-bulatan menyerupai noda. Lontar yang berwarna coklat sedang (5YR 3/4) akan berubah warnanya menjadi jingga keabu-abuan (10YR 7/4). Perubahan warna terjadi ketika disinari selama 15 hari.

Berdasarkan pengujian ini dapat disimpulkan bahwa cara yang paling ampuh untuk melindungi lontar dari pengaruh radiasi cahaya bukan menggunakan bahan konservasi, tetapi dengan menyimpan lontar jauh dari paparan cahaya. Data

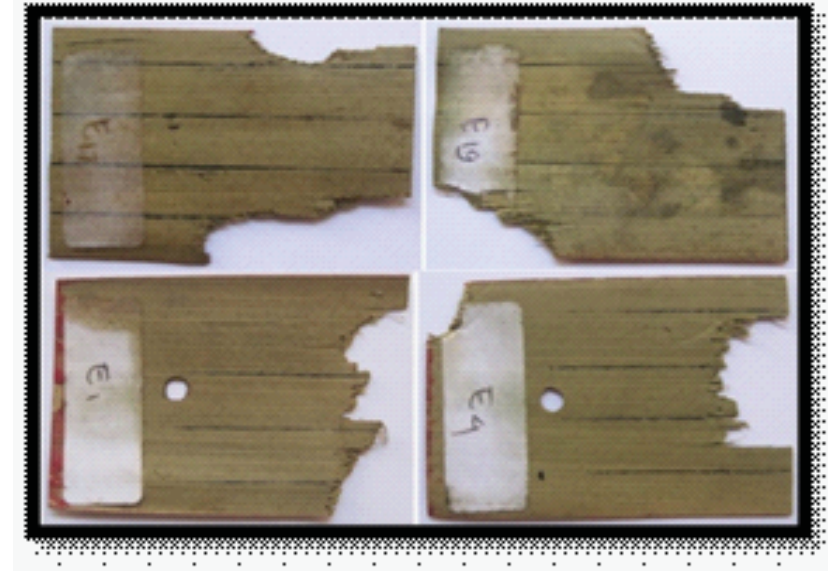

Gambar 11. Bagian tepi lontar yang rusak karena dimakan rayap

penurunan kualitas kelenturan lontar ketika disinari dengan lampu pijar yang menghasilkan suhu $31^{\circ} \mathrm{C}$ dapat dilihat pada Tabel 6.

Hasil pengujian lontar terhadap serangan rayap yaitu terjadi perubahan pada bentuk lontar. Bentuk lontar setelah mengalami proses pengujian tidak lagi berbentuk persegi panjang. Hal ini karena bagian tepi lontar mengalami kerusakan akibat dimakan oleh rayap.

Data hasil pengamatan terhadap kondisi lontar pada pengujian ini dapat dilihat pada Tabel 7. Berdasarkan Tabel 7 di atas, bahan-bahan konservasi yang digunakan mampu melindungi lontar dari serangan rayap. Hal ini dapat dilihat dari perbandingan

Tabel 6. Data Penurunan Kualitas Kelenturan Lontar

Selama Disinari dengan Lampu Pijar yang Menghasilkan Suhu $31^{\circ} \mathrm{C}$

\begin{tabular}{cl}
$\begin{array}{c}\text { Lama } \\
\text { Paparan }\end{array}$ & \multicolumn{1}{c}{$\begin{array}{c}\text { Kode Lontar yang Mengalami } \\
\text { Penurunan Kualitas Kelenturan }\end{array}$} \\
\hline 8 hari & D0* \\
\hline 10 hari & D1, D6, D11 \\
\hline 12 hari & D3, D4, D7, D8, D17, D24, D30, D33, D35, dan D38 \\
\hline 13 hari & D2, D9, D14, D20, D22, D27, D34, D37, D40, dan D44 \\
\hline 18 hari & $\begin{array}{l}\text { D5, D10, D12, D13, D15, D16, D18, D19, D21, D23, D25, D26, D28, D29, D31, D32, D36, } \\
\text { D39, D41, D42, dan D43 }\end{array}$ \\
\hline
\end{tabular}

* Ket: lontar yang tidak diolesi bahan konservasi 
Tabel 7. Hasil Pengamatan Kondisi Lontar Terhadap Serangan Rayap

\begin{tabular}{|c|l|}
\hline Lama Penyimpanan & \multicolumn{1}{|c}{ Kode Lontar yang Dimakan Rayap } \\
\hline 1 hari & E0* \\
\hline 13 hari & E3, E15, E32, E22, dan E37 \\
\hline 14 hari & E12, E6, E8, E7, E10, dan E30 \\
\hline 15 hari & E4, E11, E21, E24, dan E28 \\
\hline 16 hari & E9, E13, E14, E19, E31, dan E36 \\
\hline 17 hari & E16, E17, E18, dan E29 \\
\hline 18 hari & E20, E26, E33, E40, dan E44 \\
\hline 19 hari & E2, E5, E23, E27, E35, dan E39 \\
\hline 20 hari & E25, E34, E38, E41, E42, dan E43 \\
\hline
\end{tabular}

* Keterangan: lontar yang tidak diolesi bahan konservasi

antara lontar yang tidak diolesi bahan konservasi (E0) lebih cepat dimakan rayap dibandingkan dengan lontar yang telah diolesi bahan konservasi. Kemungkinan besar ini terjadi karena zat aktif yang terdapat pada bahan-bahan konservasi tersebut tidak disukai oleh rayap. Contohnya geraniol yang terdapat pada minyak sereh (Feriyanto, dkk, 2013: 10).

Hasil pengujian lontar pada kondisi nyata yaitu kelenturan lontar berkurang. Lontar yang telah diuji apabila dibengkokan $180^{\circ}$ mudah patah. Hasil pengamatan terhadap kualitas kelenturan lontar saat pengujian lontar pada kondisi nyata dapat dilihat pada Tabel 8.

\section{B. Hasil Penilaian Kualitas Bahan Konservasi}

Penilaian bahan konservasi dilakukan untuk mendapatkan bahan yang paling efektif dari 44 jenis bahan konservasi yang digunakan. Cara penilaian yaitu dengan menghitung poin pada setiap pengujian yang dilakukan (pengujian kondisi ekstrim dan pengujian kondisi nyata). Poin nilai yang diberikan untuk bahan-bahan konservasi dibagi menjadi tiga kategori yaitu A (sangat ampuh), B (ampuh), dan C (kurang ampuh).

1. Pengujian terhadap pengaruh suhu tinggi

a. Kategori A (Sangat ampuh)

Mampu mempertahankan kelenturan lontar selama 17 hari dan mampu mempertahankan warna awal lontar

b. Kategori B (Ampuh)

Mampu mempertahankan kelenturan lontar selama 12 hari dan mampu mempertahankan warna awal lontar

c. Kategori C (Kurang ampuh)

- Mampu mempertahankan kelenturan lontar $\geq 12$ hari namun tidak mampu mempertahankan warna awal lontar

- Tidak mampu mempertahankan kelenturan lontar selama 12 hari namun mampu atau

Tabel 8. Data Pengamatan Kualitas Kelenturan Lontar pada Pengujian Kondisi Nyata

\begin{tabular}{|c|c|c|}
\hline $\begin{array}{l}\text { Kondisi } \\
\text { Kelenturan } \\
\text { Lontar }\end{array}$ & Lontar yang diuji & Lama Penyimpanan \\
\hline \multirow{3}{*}{ Menurun } & $\mathrm{FO}^{*}, \mathrm{GO}^{*}, \mathrm{HO}^{*}$ & 39 hari \\
\hline & F1, F6, F11, G1, G6, G11, H1, H6, dan H11 & 41 hari \\
\hline & $\begin{array}{l}\text { F3, F4, FA7, F8, F17, F24, F30, F33, F35, F38, G3, G4, G7, } \\
\text { G8, G17, G24, G30, G33, G35, G38, H3, H4, H7, H8, H17, H24, } \\
\text { H30, H33, H35, dan H38 }\end{array}$ & 42 hari \\
\hline Tetap/Baik & $\begin{array}{l}\text { F2, F5, F9, F10, F12, F13, F14, F15, F16, F18, F19, F20, F21, } \\
\text { F22, F23, F25, F26, F27, F28, F29, F31, F32, F34, F36, F37, } \\
\text { F39, F40, F41, F42, F43, F44, G2, G5, G9, G10, G12, G13, } \\
\text { G14, G15, G16, G18, G19, G20, G21, G22, G23, G25, G26, } \\
\text { G27, G28, G29, G31, G32, G34, G36, G37, G39, G40, G41, } \\
\text { G42, G43, G44, H2, H5, H9, H10, H12, H13, H14, H15, H16, } \\
\text { H18, H19, H20, H21, H22, H23, H25, H26, H27, H28, H29, H31, } \\
\text { H32, H34, H36, H37, H39, H40, H41, H42, H43, dan H44 }\end{array}$ & 42 hari \\
\hline
\end{tabular}

* Keterangan: lontar yang tidak diolesi bahan konservasi 
tidak mampu mempertahankan warna awal lontar.

2. Pengujian lontar terhadap pengaruh udara lembab

a. Kategori A (Sangat ampuh)

Mampu menghambat pertumbuhan jamur selama 33 hari dan mampu mempertahankan warna awal lontar

b. Kategori B (Ampuh)

Mampu menghambat pertumbuhan jamur selama 31 hari dan mempertahankan warna awal lontar

c. Kategori C (Kurang ampuh)

Mampu menghambat pertumbuhan jamur $\geq 31$ hari namun tidak mampu mempertahankan warna awal lontar

- Tidak mampu menghambat pertumbuhan jamur selama 31 hari namun mampu atau tidak mampu mempertahankan warna awal lontar

3. Pengujian lontar terhadap pengaruh fluktuasi suhu

a. Kategori A (Sangat ampuh)

Mampu mempertahankan bentuk awal lontar selama 41 hari dan mampu mempertahankan warna awal lontar

b. Kategori B (Ampuh)

Mampu mempertahankan bentuk awal lontar selama 37 hari dan mampu mempertahankan warna awal lontar

c. Kategori C (Kurang ampuh)

- Mampu mempertahankan bentuk awal lontar $\geq 37$ hari namun tidak mampu mempertahankan warna awal lontar

- Tidak mampu mempertahankan bentuk awal lontar selama 37 hari namun mampu atau tidak mampu mempertahankan warna awal lontar

4. Pengujian lontar terhadap pengaruh radiasi cahaya

a. Kategori A (Sangat ampuh)

Mampu mempertahankan warna awal lontar $>15$ hari

b. Kategori B (Ampuh)

Mampu mempertahankan warna awal lontar selama 15 hari

c. Kategori C (Kurang ampuh)

Tidak mampu mempertahankan warna awal lontar selama 15 hari

5. Pengujian lontar terhadap serangan serangga

a. Kategori A (Sangat ampuh)

Mampu mempertahankan bentuk awal lontar selama 19 hari dan mampu mempertahankan warna awal lontar

b. Kategori B (Ampuh)

Mampu mempertahankan bentuk awal lontar selama 18 hari dan mampu mempertahankan warna awal lontar

c. Kategori C (Kurang ampuh)

- Mampu mempertahankan bentuk awal lontar $\geq 18$ hari namun tidak mampu mempertahankan warna awal lontar

6. Tidak mampu mempertahankan bentuk awal lontar selama 18 hari namun mampu atau tidak mampu mempertahankan warna awal lontarPengujian lontar pada kondisi nyata

a. Kategori A (Sangat ampuh)

Mampu mempertahankan kelenturan lontar > 41 hari dan mampu mempertahankan warna awal lontar

b. Kategori B (Ampuh)

Mampu mempertahankan kelenturan lontar selama 41 hari dan mampu mempertahankan warna awal lontar

c. Kategori C (Kurang ampuh)

- Mampu mempertahankan kelenturan lontar $\geq 41$ hari namun tidak mampu mempertahankan warna awal lontar

- Tidak mampu mempertahankan kelenturan lontar selama 41 hari namun mampu atau tidak mampu mempertahankan warna awal lontar.

Berdasarkan model penilaian bahan konservasi, didapatkan total poin A (sangat ampuh) terbanyak yaitu 5 poin. Bahan-bahan konservasi yang mendapatkan poin A (sangat ampuh) sebesar 5 poin, dapat dilihat pada Tabel 9.

Berdasarkan model penilaian bahan konservasi (lampiran 2), dapat disimpulkan bahwa:

1. Bahan konservasi yang sangat ampuh untuk melindungi lontar dari pengaruh suhu panas yaitu:

a. Bahan konservasi No. 5: campuran gliserin dan etanol. 
Tabel 9. Bahan Konservasi dengan Poin A (Sangat Ampuh) Terbanyak

\begin{tabular}{cl}
$\begin{array}{c}\text { No } \\
\text { Bahan }\end{array}$ & \multicolumn{1}{c}{ Jenis bahan Konservasi } \\
2 & Minyak cengkeh \\
5 & Campuran gliserin dan etanol \\
23 & Campuran minyak cengkeh, gliserin, dan etanol \\
25 & Campuran minyak cengkeh, gliserin, etanol, aseton, dan minyak sereh \\
41 & Campuran minyak sereh, minyak cengkeh, gliserin, dan etanol \\
\hline
\end{tabular}

Tabel 10. Bahan Konservasi yang Paling Efektif

Berdasarkan Penghitungan Poin (A+B) Terbanyak

\begin{tabular}{|cl} 
No Bahan & Jenis Bahan Konservasi \\
\hline 2 & Minyak cengkeh \\
\hline 5 & Campuran gliserin dan etanol \\
\hline 23 & Campuran minyak cengkeh, gliserin, dan etanol \\
\hline
\end{tabular}

b. Bahan konservasi No. 23: campuran minyak cengkeh, gliserin, dan etanol.

c. Bahan konservasi No. 25: campuran minyak cengkeh, gliserin, etanol, aseton, dan minyak sereh.

d. Bahan konservasi No. 41: campuran minyak sereh, minyak cengkeh, gliserin, dan etanol.

2. Bahan konservasi yang sangat ampuh untuk menghambat pertumbuhan jamur pada lontar yaitu:

a. Bahan konservasi No. 2: minyak cengkeh.

b. Bahan konservasi No. 5: campuran gliserin dan etanol.

c. Bahan konservasi No. 23: campuran minyak cengkeh, gliserin, dan etanol.

3. Bahan konservasi yang sangat ampuh untuk melindungi lontar dari pengaruh fluktuasi suhu yaitu bahan konservasi No. 2: minyak cengkeh.

4. Bahan konservasi yang sangat ampuh untuk melindungi lontar dari serangan serangga yaitu:

a. Bahan konservasi No. 25: campuran minyak cengkeh, gliserin, etanol, aseton, dan minyak sereh.

b. Bahan konservasi No. 41: campuran minyak sereh, minyak cengkeh, gliserin, dan etanol.

Untuk mendapatkan bahan konservasi yang efektif dari ke-5 bahan konservasi di atas, dilakukan penjumlahkan poin A (sangat ampuh) dan B (ampuh).
Berdasarkan model penilaian bahan konservasi (lampiran 2), didapatkan bahan konservasi dengan total poin $(A+B)$ terbanyak yaitu 7 poin. Bahan-bahan konservasi tersebut dapat dilihat pada tabel berikut.

\section{Penutup}

Berdasarkan hasil eksperimen yang dilakukan terhadap lontar yang telah dilapisi bahan-bahan konservasi, terdapat tiga jenis bahan konservasi yang efektif untuk melindungi lontar dari pengaruh suhu panas, pengaruh fluktuasi suhu, serangan serangga, dan menghambat pertumbuhan jamur pada lontar, yaitu:
a. Minyak cengkeh
b. Campuran gliserin dan etanol
c. Campuran minyak cengkeh, gliserin, dan etanol

\section{Rekomendasi}

Bahan konservasi ini efektif melindungi lontar apabila digunakan selama sebulan. Setelah satu bulan proses konservasi dilakukan lagi. Sebaiknya bahan konservasi seperti minyak kemiri dan campuran minyak kemiri dengan gliserin tidak digunakan karena dapat mengubah warna lontar. Cara penyimpanan lontar dapat menggunakan kotak kayu atau lemari kaca, namun setiap satu hari sekali kotak kayu atau lemari kaca tersebut harus dibuka agar terjadi sirkulasi udara dalam tempat penyimpanan tersebut. 


\section{Daftar Pustaka}

Agrawal, O.P., 1977, Care and Preservation of Museum Objects. New Delhi : The Manager Government Of India Press, Faridabad

Dureau, J.M. dan Clements D.W.G., 1986, Principles for the Preservation and Conservation of Library Materials, The Hague, IFLA.

Feriyanto, Eko Y., Sipahutar PJ., Mahfud, dan Prihatini P., 2013, "Pengambilan Minyak Atsiri dari Daun dan Batang Serai Wangi (Cymbopogon winterianus) Menggunakan Metode Distilasi Uap dan Air dengan Pemanasan Microwave" dalam Jurusan Teknik Kimia Volume II. No.2: 10-16, Surabaya: Fakultas Teknologi Industri, Institut Teknologi Sepuluh Nopember (ITS).

Hadi, Sutrisno, 1985, Metodology Research, Yogyakarta: Yayasan Penerbit Fakultas Psikologi UGM.
Johnson S Jessica, 2006, "Museum Collections Environment-Chapter 4" dalam Museum Handbook-Part 1, National Park Service.

Sahoo, Jyotshna, 2004, "Preservation of Library Materials : Some Preventive Measures", OHRJ, Vol. XLVII, No. 1. orissa.gov. in / e-magazine/Journal/jounalvol1 / pdf/ orbj-14.pdf .

Samson, R.A., E.S. Hoekstra, J.C. Frisvad and O. Filtenborg, 1995, Introduction to Food Borne Fungi. 4th ed. Netherlands: Ponsen \& Looyen. 